\title{
Constructing Identity through Practice: Preservice Teachers' Narratives of Practicum
}

\section{Peter Clements \\ Shizuoka University}

\section{Reference Data:}

Clements, P. (2020). Constructing identity through practice: Preservice teachers' narratives of practicum. In P. Clements, A. Krause, \& R. Gentry (Eds.), Teacher efficacy, learner agency. Tokyo: JALT. https://doi.org/10.37546/JALTPCP2019-01

As a follow-up to a study of the published accounts of preservice teachers (PSTS) in Japan, I conducted interviews with three PSTs before and after their final teaching practicum. The narrative framework and themes generated in the previous study served as a guide to examining the settings, times, and people that the PSTs suggested were significant to their practicum experience. The results complicate and extend the previous findings, providing insight into how the PSTs dealt with stress and negative episodes as well as how their identities as teachers developed through practice. The PSTs' relationships with their students were key in this regard, while mentoring teachers tended to play an evaluative and disciplinary role that was less central to development. This has implications for how teachers who work with PSTs can productively intervene to promote reflective growth.

本研究は、先に行われた実習生の感想文を分析した結果に基づく調査である。教育実習の前後に3人の実習生ヘインタビ ユーを行い、前回のナラティヴ枠組やテーマを使い、実習期間を通して実習生にとつての重大な場所・時間・人々を調べた。結 果は前回の結果より詳細であり、特に実習生がストレスや困ったことをどのように対処したか、また教師としてのアイデンティ

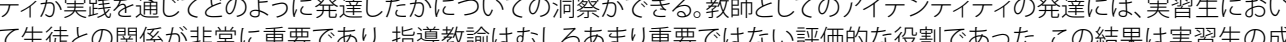
長を促す指導方法に重要な示唆となる。

urrent research recognizes that preservice teachers (PSTs) are not passive receivers of skills and knowledge and that teacher education involves a complex interaction of personal, institutional, and sociocultural factors that contribute to the ongoing construction of professional identity (e.g., Yuan \& Lee, 2015). Informed by an understanding of identity as discursively constructed (Gee, 2000; Sfard \& Prusack, 2005), recent investigations of the teaching practicum have drawn attention to the "identity work" (Trent, 2013) that PSTs must undertake in order to integrate "disparate personal and professional subjectivities...leading toward the ideological integration of multiple senses of self" (Alsup, 2006, p. 36). Researchers have suggested that PSTs' ability to reconcile these varying identity positions (or subjectivities) is key to whether they continue on as teachers or withdraw from the profession (Alsup, 2006; Trent, 2018).

In Japan, however, PST education has generally been considered of marginal importance compared with inservice training for full-time teachers (Howe, 2005). Thus, it is not surprising that few studies have focused on PSTs' accounts of their practicum experiences. Exceptions include Asada's (2007) study of three PSTs completing a kindergarten practicum, which suggested that onsite mentoring was not always facilitative of professional development. In EFL, Fujieda (2010) conducted a case study of one PST during a high school English-teaching practicum, finding that the PST's beliefs about teaching conflicted at times with the realities of teachers' other duties and resulted in the PST developing a negative stance towards the profession. More recently, Nekoda (2018) interviewed 11 PSTs immediately after a practicum, focusing on the problems they encountered while teaching English and how they dealt with those problems via the mediation of mentoring teachers.

Here I build on this work through an analysis of interviews with three PSTs in their final year of university. This follows from a previous study (Clements, 2019) of PSTs' published narratives by contrasting the relative breadth of that study with a more detailed investigation of a small number of participants. Using the same narrative framework of place, time, and people (Clandinin \& Connelly, 2000), I look at the way the PSTs incorporated these elements, this time using pre- and postpracticum interviews. Besides the chance to compare in-depth interview responses with public accounts, this also allows for insight into the particularity of PSTs' practicum experiences. Specifically, I examine their efforts at taking the varied situations of the practicum and investing those 
situations with coherence and meaning in relation to their personal and career goals, which provides a window on their developing teacher identities.

\section{Method}

The participants in this study were three Japanese students in their final year in the education faculty of a national university located in central Japan. Two of them were in the English education program and had to complete 3 practicum sessions over 3 years in order to be certified for a teacher's license, which was also a university graduation requirement. During the study, they completed their final 2-week session, both at elementary schools. The third participant was in the international understanding program and had chosen to get a teacher's license though it was not a requirement. During the study she completed all her practicum requirements at once in two consecutive 2-week sessions, the first at a junior high school and the second at a senior high school. Informed consent was obtained from all participants, and the project was formally cleared with the university. Table 1 summarizes participant information.

\section{Table 1. Participant Information}

\begin{tabular}{llll}
\hline Name (sex) & Major & $\begin{array}{l}\text { Study-abroad } \\
\text { experience }\end{array}$ & Practicum length/level \\
\hline Connor (male) & English education & 1 year/Canada & $\begin{array}{l}2 \text { weeks/ } \\
\text { elementary }\end{array}$ \\
Hatsumi (female) & English education & 2 months/US & $\begin{array}{l}2 \text { weeks/ elementary } \\
\text { Kei (female) }\end{array}$ \\
& $\begin{array}{l}\text { International } \\
\text { understanding }\end{array}$ & 10 months/US & $\begin{array}{l}2 \text { weeks each /junior high } \\
\text { and high school }\end{array}$ \\
\hline
\end{tabular}

Note. All names are pseudonyms chosen by the participants themselves.

Semi-structured interviews conducted before and after the practicum sessions provided the main source of data. Initial interviews (around 45 minutes each) focused on personal and educational background, L2 learning history and attitudes, career plans, teaching self-image, and expectations regarding practicum. Follow-up interviews (23-34 minutes) dealt with overall practicum experience, relationships with others, unexpected and significant events, and any changes in self-image and career plans since the first interview. The interviews, which took place in my office, were primarily in English, though I stressed that participants were free to use Japanese. Both Connor and Kei spoke mainly in English, occasionally resorting to words and short phrases in Japanese, while Hatsumi frequently responded at length in Japanese, with me recasting in English to confirm her intended meaning and my own understanding. The use of English and Japanese in this way was quite similar to my interactions with other students at this university. See Appendix A for a list of interview topics.

Besides interviews, I had participants complete written narrative frames before and after the practicum. A narrative frame (Barkhuizen, 2014) is a series of prompts that scaffold the composing of a story. I used frames with parallel prompts (see Appendix B) to encourage participants to think about their practicum experience in narrative terms. I also observed each of the PSTs teaching a class during practicum (although I was only able to observe Kei during her second practicum at a senior high school). Narrative frames and observation notes provided supplementary sources of data and topics for discussion during follow-up interviews.

As noted earlier, I examined PSTs' published narratives of practicum according to Clandinin and Connelly's (2000) three-dimensional narrative space (Clements, 2019). This framework provided information about the places, times, and people that PSTs considered significant in their practicum experiences, which I used in the current study to guide interviews and analysis. After transcribing the interviews, I read through the materials both cross-sectionally (at each point in time) and longitudinally (for each participant), assigning codes and then themes. I then wrote a series of analytic memos (Miles, Huberman, \& Saldaña, 2014) in which I constructed a narrative of each participant's practicum experience and sent it to the participant for member checking, allowing participants to review and disagree with my interpretations and state whether they wanted any details removed. In the following analysis, I have relied mainly on memos in synthesizing the three participants' narratives according to each of the three dimensions. Quotes from the participants have not been edited for grammatical accuracy.

Analysis

Place

The participants tended to refer to place indirectly, focusing when they did so on the practicum site itself. The type of school was particularly important, with contrasts being made between junior high and elementary school or junior and senior high school.

Connor and Hatsumi, who had both completed a practicum session the previous year at junior high school (as well as a short practicum at elementary school a year before that), 
were both expecting their third (elementary school) practicum to be quite different, and suggested that one of their goals was to learn more about the different demands of each type of school. Connor also observed that "environment is a big deal" when learning how to interact with students and suggested that one challenge would be to control the elementary school students because they were "super-energetic." Kei, who completed consecutive sessions at junior and senior high school, later noted specific differences between the demands placed on teachers: junior high school was more restrictive of teachers' time, while senior high was more flexible, allowing them to go home earlier. She also described working at senior high school as more focused on preparing lesson materials, while teachers at junior high school had to be more concerned with students' overall growth rather than just language learning.

The narratives further implied a distinction between what happens in the classroom and what happens elsewhere. All three participants described their interactions with students as key to their development as teachers, and these interactions occurred primarily in the classroom. Hatsumi and Kei referred to the classroom, particularly the lesson in progress, as the place to understand, in Hatsumi's words, students' "true mind." In contrast, a vaguely defined space outside of class was associated with more stressful demands: making and revising lesson plans, consulting with and occasionally being disciplined by mentoring teachers, and sharing experiences with other PSTs. For example, Kei described having to stay at the junior high school until 7 p.m. every day in order to take part in a meeting with other PSTs and discuss the events of the day.

\section{Time}

The time dimension relates first to the participants' placing of the practicum within a career trajectory. All three participants had fairly specific career plans before the practicum started, none of which had changed significantly by the final interview. Connor had been working at a cram school (juku) since starting university and was planning to continue doing that full-time after graduation, noting that he liked his students and got a sense of fulfillment from seeing them "improve their skill," but that he did not "want to take care of club activities" (a typical duty of public school teachers). Kei and Hatsumi both saw public school teaching as part of their future careers, though in different ways. Kei said, "I think it's important to keep working as a teacher," but "my goal is not teaching English to kids for my life." Instead, she planned to become a teacher and quit after a few years, hopefully to return to the US (where she had spent 10 months studying) and work in a non-educational field. Hatsumi, on the other hand, planned to eventually become a public school teacher after working for several years in the private sector, noting that "I'm concerned about only student experience." She had worked at a number of different part-time jobs during university and felt that it was important to have a variety of experiences outside of school in order to be a better teacher.

Time also relates to the participants' expectations prior to practicum and their reflections on it afterward. Initially, all three participants expressed various concerns about the practicum, and only Connor indicated that he felt ready for it. Based on their previous experiences, Connor and Hatsumi seemed most concerned about classroom management and their interactions with students. Connor stated that his first (elementary school) practicum had been "terrible" because he had been unable to control students during a lesson, but that during his second (junior high school) practicum he had become better able to predict "what will happen" during class and prepare accordingly, which was why he felt ready. Hatsumi was also concerned about classroom management, noting that the large class size (around 30) would make it difficult to respond to individual students (especially regarding English). Kei's initial expectations were understandably much less specific and based on what she had heard from friends about practicum: that it would be stressful and "really busy," that "you can't sleep," but that "sometimes it's heartwarming."

The participants' reflections after practicum contrasted in various ways with their initial expectations. Connor, who had seemed the most confident beforehand, described his practicum in his second narrative frame as "so hard and difficult" because he had had to teach other subjects besides English, a challenge that he had dealt with by "cutting off my time of sleeping" in order to prepare. Kei and Hatsumi were more positive, with Kei indicating that her two practicum sessions had been busy and stressful at times, but useful overall. When I asked Hatsumi about the concerns she had expressed beforehand she said that she had not found it especially difficult to manage a large class of students, and that her third practicum had generally been a lot smoother and less demanding than the first two. These contrasts between initial expectations and final reflections, however, are also related to specific occurrences during the practicum (discussed in more detail below).

People

The people dimension encompasses the PSTs' teaching self-images, including the experiences and expectations that they brought to practicum and how it influenced their self-image, as well as their interactions with others during practicum, specifically other PSTs, mentoring teachers, and students. I consider each of these areas in turn. 
Self

Besides career plans (discussed earlier), the PSTs' practicum experiences were informed by how they saw themselves as language learners and teachers. Connor, who had spent a year studying in Canada, was reserved about his L2 abilities ("I can communicate" but "I don't think I'm super good at English"), and stated that his learning goals were making friends and learning about other countries through English. Based on his previous practicum and part-time (cram school) teaching experiences, Connor described himself as a friendly teacher who was able to easily talk to students, adding during his second interview that, "Now I care about what I talk when I talk with student...[I] try to listen to what the student is talking about...[and their] concerns." Kei, who had also spent 10 months abroad, suggested that her attitude toward L2 learning had consequently shifted to focus more on communicating with friends instead of "studying by book or like writing." In her practicum sessions, she attempted, with somewhat mixed results, to introduce activities with a communicative and practical orientation. She also characterized herself as a teacher who tried to understand students' perspectives, which she found particularly challenging with high school students. Finally, Hatsumi, who had completed a 2-month study-abroad program the previous year and was perhaps the least confident in her L2 abilities, suggested that one of her strengths as a language teacher was her understanding of how difficult it is to learn a foreign language. Similar to the others, she characterized herself as an approachable and observant teacher who wanted to "build trust relationship to students" and who was aware that "each student have their own opinion and way to think."

I elicited participants' views on teaching by asking them what makes an effective teacher, both in general and in language teaching. Here as well, they tended to provide similar responses that were consistent with their self-images. Specifically, effective teachers were able to teach in ways that stimulated students' interests and encouraged them to express themselves. Effective teachers also, according to Kei, spent time with students and tried to "listen to what they are thinking about." According to Kei and Hatsumi, language teachers needed to be especially concerned with students' interests and motivation in order to get them to take on the enormous task of learning a foreign language, while Connor suggested that teachers' L2 proficiency was important, especially pronunciation. In contrast, ineffective teachers used mechanical teaching methodswhat Hatsumi called "read and repeat"-and according to Kei, focused on themselves by boasting of their own $\mathrm{L} 2$ abilities and being more concerned about "working condition" than student learning. The participants confirmed and extended these views during the second interview. For example, Connor stated that experience was very important for teachers, as was providing students with "opportunities to communicate," and Hatsumi suggested that effective teachers made use of their individual strengths.

\section{Others}

The people that the participants interacted with during practicum included other PSTs, mentors, and students. Interactions with other PSTs were described as mainly focusing on the sharing of difficult and stressful aspects of the practicum. For example, Connor said he talked to other PSTs about how to "get over the difficulties of teaching practice," particularly losing sleep over lesson planning. He described one PST whose university major was Japanese and who, similar to himself, had had problems preparing for a science lesson. In contrast, Kei described another PST whose experiences at the high school where she completed her second practicum had been quite different from her own. This PST, who taught Japanese, was not required to make the detailed lesson plans that Kei was, but she had to teach more often and prepare materials for the other teachers, which was part of all the Japanese teachers' regular duties. As a result, Kei stated, the PST "was crying every day" because whenever she made an error in preparing materials she had to write a note of explanation and apology to the other teachers. Kei cited this as evidence of the fact that the high school was not used to hosting PSTs, resulting in quite varied expectations, which she suggested was somewhat unfair.

Interactions with mentors were also associated with stressful and difficult aspects of the practicum, though in quite different ways. Mentors were usually presented in positive terms and described as having a parental role that combined care and discipline. For example, Kei described her junior high mentor as a "mother" who was always checking up on the PSTs and talking with them. Also, Hatsumi described her mentor as a "very good teacher" who had directed her to change specific parts of her lesson plans while allowing her to keep her own overall approach and who was able to discipline students when necessary. Connor, however, was more ambivalent about his mentor: "he was very kind... he tried to like care about me...but he was also very strict...so I had to care about what I talk to him." Connor cited several instances in which he had been disciplined, one of which involved his plans for a science lesson (referred to earlier): "I didn't really know what I do... so the teacher was kind of angry and...you should think about more." Connor's description of his reaction to this ("I was so scared") recalled his career plans: "my major is not science so...I kind of, why l'm so scold[ed]." In this sense the PSTs' relationships with mentors seemed to align them with the students as objects of mentors' care and discipline.

In contrast, the PSTs presented their relationships with students as overwhelmingly positive. The students were described as "adorable" (Connor), "very powerful," able to act 
on their own initiative (Hatsumi), and satisfyingly responsive to the PSTs' efforts to plan and manage classes (although Kei reported some difficulty reading senior high school students' reactions). More importantly, all three PSTs referred to interactions with students as crucial to learning how to be a teacher, often citing specific issues that they were aware of beforehand. Connor, for example, noted that he had found it easier to maintain control during class than he had during his previous elementary school practicum (two years earlier), and I observed him making use of strategies to maintain calm during his lesson such as a hands-on-head gesture. A key event for Kei during her junior high school practicum was her use of authentic materials. While this had not gone well initially, leading her mentor to say that she had "ruined" the materials by not providing clear guidelines, she described feeling very happy because the students had made a visible effort to understand the text, which had encouraged her to revise her approach. Hatsumi, who at the outset expressed concerns about large class sizes and the resulting difficulty in understanding individual students' attitudes, later stated that she had not found it as difficult as expected to establish a "good distance" between herself and the students and that she had developed strategies for finding out more about the less participatory students such as a comment sheet that students filled out at the end of class.

\section{Discussion}

Unlike the previous study (Clements, 2019), which dealt with publicized accounts that included PSTs' actual names, this small-scale investigation focused on interviews conducted in a setting where participants were guaranteed anonymity. While it is still possible that the participants' responses were filtered by what they felt was appropriate to share, their narratives complicate and extend the previous study in ways that resonate with other work, as follows. While the overall emotional arc of the narratives, moving from anxiety to a sense of accomplishment, is similar to the published accounts (see also Yuan \& Lee, 2016), the participants also described negative episodes, including being disciplined by mentors. These were perhaps not as disruptive as the confrontations reported elsewhere (e.g., Yuan, 2016), but they did seem to lead the PSTs to assert their own sense of self in response. For example, while talking about being "scolded" by his mentor, Connor said "my major is not science," recalling his plans to work in a setting where he could focus mainly on teaching English. Also, Connor and Kei mentioned interacting with other PSTs as a way of dealing with the stress and problems they encountered, which Gan (2014) has suggested is an important and underresearched area.

More importantly, the narratives indicate a sense of identity development through practice that accords with other studies (Alsup, 2006; Fujieda, 2010; Kanno \& Stuart,
2011). One way in which this is apparent is in the specificity of place. As noted earlier, the type of school and grade level of the students were important factors for these PSTs, and the classroom was the primary site for learning how to be a teacher, providing the opportunity for direct feedback via students' reactions. Identity development is also reflected in the PSTs' relationships with their students. Besides the emotionally positive associations that they expressed, the PSTs implied that the students were, in a sense, their best teachers. They mentioned specific issues that they had learned about through their interactions with students, such as how to maintain control during class, how to read students' reactions, and how to access the responses of less active students. In contrast, while mentors were described as caring and "good teachers," they seemed to play more of an evaluative and disciplinary role that focused on PSTs' behavior and their lesson plans (as when Kei's mentor stated that she had "ruined" the authentic materials). This seems to align mentors more closely with notions of success and failure rather than learning (cf. Timoštšuk \& Ugaste, 2010).

\section{Conclusion}

As this study focused on the responses of three PSTs, it is not possible to generalize their experiences to those of other PSTs. Indeed, the goal was rather to extend the more general findings of the previous study via the detailed accounts of three individuals, thus affording a window on some of the less positive and potentially more problematic aspects of the practicum. This is clearly a valuable line of inquiry, and further work in this area could draw on PSTs' stories over the course of several practicum sessions. As noted earlier, two of the participants in this study were completing their third and final practicum in as many years. Asking PSTs to tell their stories before and after each practicum would likely provide valuable insight into how their sense of identity as language learners and teachers develops over time and through practice. A more challenging but arguably more important project would compare practicum experiences like those reported here with the experiences of the same PSTs after they graduate and begin working as teachers.

This study also suggests that those who work with PSTs would do well to encourage their students to discuss issues like the ones raised here before and after they complete a practicum, thus engaging in what Johnson and Golombek (2016) refer to as "responsive mediation": deliberate intervention that capitalizes on the productive tension created by conflicting identity positions in order to stimulate PSTs' reflective growth. One way of realizing this in practice is to have PSTs share their stories and then analyze them, perhaps in the context of discussion with other PSTs and feedback from the teacher (see 
Barkhuizen, 2008, 2016, for a possible framework). This can help make the practicum a more meaningful part of the identity work of PSTs on their way to becoming teachers.

\section{Bio Data}

Peter Clements is associate professor at Shizuoka University. His research interests include second language writing, study abroad, and language teacher training. <peter@ shizuoka.ac.jp>

\section{References}

Alsup, J. (2006). Teacher identity discourses: Negotiating personal and professional spaces. Mahwah, NJ: Erlbaum. https://doi.org/10.4324/9781410617286

Asada, T. (2007). 幼稚園教育実習におけるメン㚈ングの機能に関する研究 [Student teaching in kindergarten: Functions of mentoring]. The Annual Report of Educational Psychology in Japan, 46, 156-165. https://doi.org/10.5926/arepj1962.46.0_156

Barkhuizen, G. (2008). A narrative approach to exploring context in language teaching. ELT Journal, 62(3), 231-239. https://doi.org/10.1093/elt/ccm043

Barkhuizen, G. (2014). Revisiting narrative frames: An instrument for investigating language teaching and learning. System, 47(1), 12-27. https://doi.org/10.1016/j.system.2014.09.014

Barkhuizen, G. (2016). A short story approach to analyzing teacher (imagined) identities over time. TESOL Quarterly, 50(3), 655-683. https://doi.org/10.1002/tesq.311

Clandinin, D. J., \& Connelly, F. M. (2000). Narrative inquiry: Experience and story in qualitative research. San Francisco, CA: Jossey-Bass.

Clements, P. (2019). Preservice teachers' narratives of practicum. In P. Clements, A. Krause, \& P. Bennett (Eds.), Diversity and inclusion. Tokyo: JALT. https://doi.org/10.37546/JALTPCP2018-10

Fujieda, Y. (2010). Exploration of teaching and construction of teacher identity through teaching practicum: A case study of a pre-service Japanese EFL teacher. Kyoai Gakuen Maebashi Kokusai Daigaku Ronshu, 10, 111-123.

Gan, Z. (2014). Learning from interpersonal interactions during the practicum: A case study of non-native ESL student teachers. Journal of Education for Teaching, 40(2), 128-139. https://doi.org/10.1080/02607476.2013.869969

Gee, J. P. (2000). Identity as an analytic lens for research in education. Review of Research in Education, 25(1), 99-125. https://doi.org/10.3102/0091732x025001099

Howe, E. R. (2005). Japan's teacher acculturation: Critical analysis through comparative ethnographic narrative. Journal of Education for Teaching, 31(2), 121-131. https://doi.org/10.1080/02607470500127251
Johnson, K. E., \& Golombek, P. R. (2016). Mindful L2 teacher education: A sociocultural perspective on cultivating teachers' professional development. New York: Routledge. https://doi.org/10.4324/9781315641447

Kanno, Y., \& Stuart, C. (2011). Learning to become a second language teacher: Identities-inpractice. The Modern Language Journal, 95, 236-252. https://doi.org/10.1111/j.1540-4781.2011.01178.x

Miles, M. B., Huberman, A. M., \& Saldaña, J. (2014). Qualitative data analysis: A methods sourcebook (3rd ed.). Thousand Oaks, CA: SAGE.

Nekoda, K. (2018). 英語科教育実習生はどのような経験をしているのか: 実習生の語りによる質的研究 [What do student teachers of English experience during their practicum? A narrative study]. Yamaguchi Daigaku Kyouiku Gakubu Fuzoku Kyouiku Jissen Sougou Sentaa Kenkyuu Kiyo, 45, 1-10.

Sfard, A., \& Prusack, A. (2005, May). Telling identities: In search of an analytic tool for investigating learning as a culturally shaped activity. Educational Researcher, 34(4), 14-22. https://doi. org/10.3102/0013189X034004014

Timoštšuk, l., \& Ugaste, A. (2010). Student teachers' professional identity. Teaching and Teacher Education, 26, 1563-1570. https://doi.org/10.1016/j.tate.2010.06.008

Trent, J. (2013). From learner to teacher: Practice, language, and identity in a teaching practicum. Asia-Pacific Journal of Teacher Education, 41, 426-440. https://doi.org/10.1080/1359866x.2013.838621

Trent, J. (2018). Why some graduating teachers choose not to teach: Teacher attrition and the discourse-practice gap in becoming a teacher. Asia-Pacific Journal of Teacher Education, 47(5), 554-570. https://doi.org/10.1080/1359866X.2018.1555791

Yuan, E. R. (2016). The dark side of mentoring on pre-service language teachers' identity formation. Teaching and Teacher Education, 55, 188-197. https://doi.org/10.1016/j.tate.2016.01.012

Yuan, R., \& Lee, I. (2015). The cognitive, social and emotional processes of teacher identity construction in a pre-service teacher education programme. Research Papers in Education, 30(4), 469-491. https://doi.org/10.1080/02671522.2014.932830

Yuan, R., \& Lee, l. (2016). "I need to be strong and competent": A narrative inquiry of a studentteacher's emotions and identities in teaching practicum. Teachers and Teaching, 22(7), 819-841. https://doi.org/10.1080/13540602.2016.1185819 


\section{Appendix A}

Interview Topics

Initial Interviews

1. Personal background: native language, family situation, parents' and siblings' education and work status

2. Educational history: location, size, and type of each school attended (elementary through secondary), courses, grades

3. Language learning history: length of L2 (English) study, focus of study at each level, opportunities for L2 use, study-abroad experience, L2 learning goals, L2 self-rating, proficiency test scores

4. Work/teaching experience: kinds of jobs, purpose in taking each job, volunteer work and purpose

5. Career plans: plans after graduation, level/type of school planning to teach at, reasons for becoming a teacher, reasons for becoming a language teacher, what makes a good/poor teacher, what makes a good/poor language teacher

6. Practicum: description of self as teacher, expectations, sense of readiness, things heard about practicum from other students, initial school visits, previous practicum experiences

\section{Follow-Up Interviews}

7. Teaching practicum: teaching self-image, practicum experience as a whole, supervising teacher, other PSTs, students, school staff, unexpected aspects, aspects that were more difficult/easier than expected, most memorable aspects
4. During teaching practice, $\mathrm{I}$ expect that will be fun/interesting because

5. During teaching practice, $\mathrm{I}$ expect that will be difficult because

6. I will deal with this difficulty by

7. I expect that teaching practice (will/will not) change me because

Follow-Up Frame

1. After graduation from university, I want to be a because

2. I think I'm a (adjective) teacher because

3. For me, teaching practice was

because

4. During teaching practice, $\mathrm{I}$ thought that was fun/interesting because

5. During teaching practice, 1 thought that was difficult because

6. I dealt with this difficulty by

7. Teaching practice (did/did not) change me because

Note. Prompts are listed here to show the content and do not reflect the format of the frames, which provided more space for written responses.

\section{Appendix B}

Narrative Frame Prompts

Initial Frame

1. After graduation from university, I want to be a because

2. I think I'm a (adjective) teacher because

3. I expect that teaching practice will be because 